\title{
Multiplex PCR of bcr-abl Fusion Transcripts in Philadelphia Positive Acute Lymphoblastic Leukemia
}

\author{
A. Lee, J. Kirk, S. Edmands, and J. Radich \\ Division of Clinical Research, Fred Hutchinson Cancer Research Center, Seattle, Washington 98104-2015
}

\begin{abstract}
We describe a multiplex PCR assay for the detection of bcr-abl fusion mRNA in Philadelphia chromosome positive acute lymphoblastic leukemia (Ph+ ALL). The assay provides a quick method for screening p190 (e1:a2) and p210 (b2:a2 or b3:a2) bcr-abl mRNAs simultaneously. The assay proves to be highly sensitive with detection of as little as one positive bcr-abl-expressing cell in a background of $10^{5}$ negative bcr-abl cells. Bone marrow and peripheral blood specimens from six patients were in total accordance when run by multiplex PCR and by the single primer PCR approach. The multiplex $b c r-a b l$ assay may prove to be highly useful for screening newly diagnosed patients with ALL for the bcr-abl fusion transcript and in following the course of disease during therapy.
\end{abstract}

Shronic myeloid leukemia (CML) and Philadelphia chromosome positive acute lymphoblastic leukemia (Ph + ALL) are characterized at the molecular level by the $b c r-a b l$ fusion transcript, which can be detected by reverse transcriptionpolymerase chain reaction (RT-PCR). ${ }^{(1)}$ In CML, the chimeric $b c r-a b l$ mRNA rises from the juxtaposition of $c-a b l$ exon 2 and either $b c r$ exon 2 or exon 3 (b2:a2 or b3:a2), which code for the chimeric p210 protein. The identical molecular finding occurs in $30 \%-50 \%$ of patients with $\mathrm{Ph}+\mathrm{ALL}^{(2)}$ The majority of Ph + ALL patients have a more $5^{\prime} \mathrm{bcr}$ breakpoint within the first large $b c r$ intron and express a fusion mRNA, e1:a2 (Fig. 1). This mRNA codes for the chimeric p190 protein. We have found that Ph + ALL patients can uncommonly have both $\mathrm{p} 210$ and p190 transcripts. ${ }^{(3)}$ Furthermore, in very rare cases, CML patients have been described as possessing the e1:a2 molecular transcript. ${ }^{(4,5)}$ Therefore, multiplex PCR would be valuable in determining the types of molecular transcripts in patients through a single PCR reaction.

Bone marrow transplantation (BMT) is the only curative therapy for CML and is often the treatment of choice for $\mathrm{Ph}+$ ALL. ${ }^{(6)}$ RT-PCR can be employed to monitor patients for the persistence of $b c r-a b l$ following BMT. RT-PCR of $b c r-$ $a b l$ routinely detects $b c r-a b l$ transcripts down to a sensitivity of $10^{-5}$ or $10^{-6}$. Follow-up of patients using this method, however, is both expensive and timeconsuming. RT-PCR requires multiple steps, each step associated with a potential of contamination. The p210 and p190 bcr-abl mRNAs are detected in separate PCR reactions, and an additional amplification of a control gene is re- quired to validate the integrity of target mRNA. For example, detection of the p210-type mRNAs (b2:a2 or b3:a2) is achieved in a single reaction along with an additional reaction for the amplification of a control gene, $\beta 2$ microglobulin. Similarly, the detection of $b c r-a b l$ in $\mathrm{Ph}+$ ALL requires a separate reaction with p190-specific primers as well as a reaction for amplification of the p210 mRNA, and a $\beta 2$ microglobulin control.

To simplify this procedure we have developed a nested, multiplex RT-PCR assay in which three sets of external primers (for the detection of p190 and p210 bcr-abl transcripts and $\beta 2$ microglobulin) are mixed simultaneously in the initial PCR amplification and three sets of internal primer pairs are combined in a second nested amplification. In addition, by combining the reverse transcription and first-stage PCR step, we have further reduced the number of manipulations, maintained sensitivity, and minimized the risk of contamination.

\section{MATERIALS AND METHODS \\ Preparation of Total RNA from Cultured Cells}

Total RNA from cultured K562, HL60, and ALL-1 cells were extracted using guanidine hydrochloride. Poly $(\mathrm{A})^{+}$RNA was isolated through Northern blotting after being electrophoresed through formaldehyde denaturing gels. ${ }^{(7)}$

\section{Patient Samples}

Bone marrow and/or peripheral blood samples were obtained after informed 


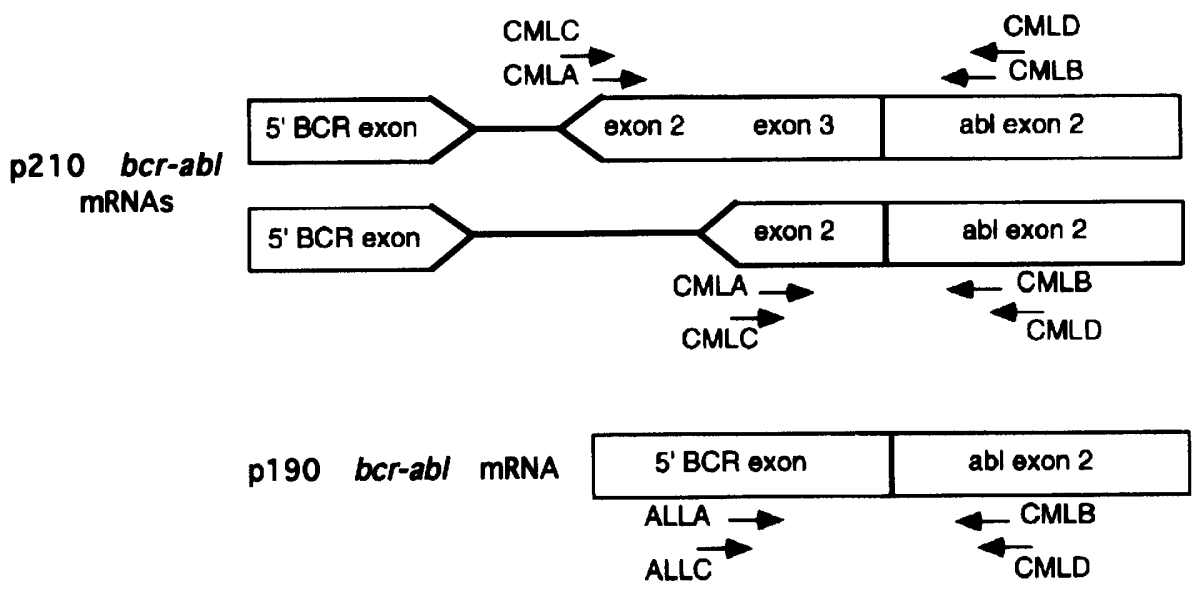

RT-PCR product

$304 \mathrm{bp}$

234bp

196bp

FICURE 1 Schematic of $b c r-a b l$ transcript PCR amplification along with the p190, p210, and $\beta 2$ microglobulin primers. Because the same 3 '-primers ( $a b l$ primers) are used in the amplification of p190 and p210 bcr-abl mRNAs, CML B and CML D are written as both the 3' ALL primers as well as the 3' CML primers.

consent from six patients with CML or $\mathrm{Ph}+\mathrm{ALL}$. These patients were enrolled in studies approved by the Internal Review Board at the Fred Hutchinson Cancer Research Center.

\section{Preparation of Serial Dilutions}

RNA dilutions were made with RNA prepared from K562 (a cell line positive for a b3:a2 p210 bcr-abl rearrangement), ALL-1 (a patient cell line positive for the e1:a2 p190 bcr-abl rearrangement), and HL60 cells (negative for any $b c r-a b l$ transcripts). Serial dilutions, from $10^{-1}$ to $10^{-6}$ concentrations, of both $\mathrm{K} 562$ and ALL- 1 were combined with a background of $1 \mu \mathrm{g}$ of total HL60 RNA to serve as positive controls for the p210 (b3:a2) and p190 (e1:a2) bcr-abl mRNAs, respectively.

\section{Preparation of Total RNA from Patient Samples}

Leukocytes were separated from patient bone marrow and peripheral blood using a $3 \%$ dextran sulfate in $1 \times$ phosphate-buffered saline (PBS) solution. Patient specimens were diluted with $20 \mathrm{ml}$ of $1 \times$ PBS and then again diluted with 20 $\mathrm{ml}$ of $3 \%$ dextran sulfate $/ 1 \times \mathrm{PBS}$ solution. After $1 \mathrm{hr}$ at room temperature, suspended leukocytes were transferred and further isolated by the use of salt lysis buffers $(0.22 \%$ and $1.6 \%$ salt lysis buffers). Leukocytes were then washed twice with ice-cold PBS and lysed in a guanidinium solution. Total RNA was extracted according to the acid guanidinium thiocyanate/phenol/chloroform method of Chomczynski and Sacchi. ${ }^{(8)}$ The RNA pellet was rehydrated with $40 \mu \mathrm{l}$ of diethylpyrocarbonate (DEPC)-treated water. Ten microliters was used directly for the coupled RT-PCR amplification step, and the remainder was stored at $-80^{\circ} \mathrm{C}$.

\section{Primers}

The relative positions of the oligonucleotides used in the nested, multiplex PCR of $b c r-a b l$, and the size of PCR products are shown in Figure 1. Primer sequences are listed in Table $1 .^{(9)}$

\section{Coupled Reverse Transcription- First-round Amplification}

Ten microliters of RNA was added to 40 $\mu l$ of the coupled reaction mixture. The mixture contained the following component concentrations in a final volume of $50 \mu \mathrm{l}: 500$ nм CMLD, 500 nм CML C, 170 nм ALL D, 170 nм ALL C, 250 пм 3'- $\beta 2$,

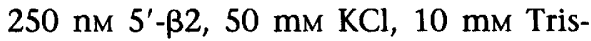
$\mathrm{HCl}(\mathrm{pH} 9.0), 0.1 \%$ Triton X-100, $200 \mu \mathrm{M}$ nucleotides, $1.5 \mathrm{mM} \mathrm{MgCl}_{2}, 4.0$ units of RNasin (Promega), 6.25 units of AMVRT (Boehringer Mannheim), 1.25 units of Amplitaq polymerase (Perkin-Elmer Cetus), and DEPC $-\mathrm{H}_{2} \mathrm{O}$. Reaction tubes were kept on ice at all times to prevent nonspecific amplification. After mineral oil overlay, the reaction tubes were placed on the thermocycler block after the block reached $85^{\circ} \mathrm{C}$. The reaction tubes were incubated for $30 \mathrm{~min}$ at $42^{\circ} \mathrm{C}$, then $5 \mathrm{~min}$ at $95^{\circ} \mathrm{C}$, followed by 40 cycles of $30 \mathrm{sec}$ at $94^{\circ} \mathrm{C}, 1 \mathrm{~min}$ at $55^{\circ} \mathrm{C}$, and 1 min at $72^{\circ} \mathrm{C}$, followed by a final elongation of $7 \mathrm{~min}$ at $72^{\circ} \mathrm{C}$ on an Omnigene thermocycler (Hybaid Ltd).

TABLE 1 Primer Sequences

\section{For $\mathrm{p} 210 \mathrm{bcr}-\mathrm{abl}$ sequences \\ CML A 5'-TGG AGC TGC AGA TGC TGA CCA ACT CG-3' \\ CML B 5'-ATC TCC ACT GGC CAC AAA ATC ATA CA-3' \\ CML C 5'-GAA GTG TTT CAG AAG CTT CTC C-3' \\ CML D 5'-TGA TTA TAG CCT AAG ACC CGG A-3' \\ For $p 190$ bcr-abl sequences \\ ALL A 5'-AGA TCT GGC CCA ACG ATG GCG AGG GC-3' \\ ALL B $\quad 5^{\prime}$-ATC TCC ACT GGC CAC AAA ATC ATA CA-3' \\ ALL C 5'-ACC ATC GTG GGC GTC CGC AAG A-3' \\ ALL D 5'-TGA TTA TAG CCT AAG ACC CGG A-3'}

For $\beta 2$ microglobulin sequences

3'B2 5'-CCT CCA TGA TGC TGC TTA CAT GTC-3'

5'32 5'-ATG TCT CGC TCC GTG GCC TTA GCT-3'

Sequences of p190 and p210 were adopted from Maurer et al. ${ }^{(9)}$ 


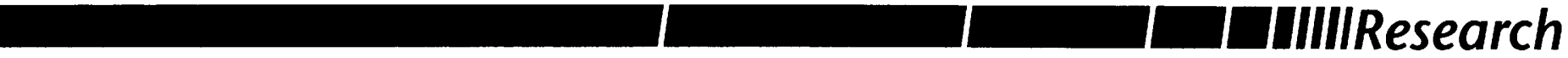

\section{Second-round Amplification}

Five microliters of the coupled reverse transcription-first-round amplification mixture was transferred to a tube containing ingredients for a second round of amplification: $500 \mathrm{~nm}$ CML B, 500 nм CML A, 170 пм ALL B, 170 nм ALL A, 75 nм 3'- $\beta 2,75$ пм 5'- $\beta 2,50$ mм KCl, 10 mм Tris- $\mathrm{HCl}(\mathrm{pH} \mathrm{9.0),} \mathrm{0.1 \%} \mathrm{Triton} \mathrm{X-100,}$ $150 \mu$ m nucleotides, $1.35 \mathrm{~mm} \mathrm{MgCl}_{2}, 1.25$ units of Amplitaq polymerase and DEPC $-\mathrm{H}_{2} \mathrm{O}$ to a final volume of $50 \mu \mathrm{l}$. Again, the reaction tubes were kept cold, overlaid with mineral oil, and placed on the thermocycler after the block reached $85^{\circ} \mathrm{C}$. The second amplification consists of a 5 -min denaturation at $95^{\circ} \mathrm{C}, 40 \mathrm{cy}$ cles at $94^{\circ} \mathrm{C}$ for $30 \mathrm{sec}, 55^{\circ} \mathrm{C}$ for $1 \mathrm{~min}$, $72^{\circ} \mathrm{C}$ for $1 \mathrm{~min}$, and a final elongation at $72^{\circ} \mathrm{C}$ for $7 \mathrm{~min}$.

\section{Electrophoretic Analysis of PCR Products}

Amplified products were run on a $2 \%$ agarose gel (GIBCO/BRL). The two p210 molecular rearrangements yield products that are $304(\mathrm{~b} 3: \mathrm{a} 2)$ and $234(\mathrm{~b} 2: \mathrm{a} 2)$ bp. The e1:a2 product is $196 \mathrm{bp}$ and the $\beta 2$ PCR product is $370 \mathrm{bp}$ (Figure 1).

\section{Controls}

For all nested-multiplex PCRs, four controls were used: a $10^{-6}$ positive $\mathrm{p} 190$ RNA control (the ALL-1 cell line), a $10^{-6}$ positive p210 RNA control (the K562 cell line), an HL60 negative control, and a water negative control. The $10^{-6}$ positive controls were made by mixing $1 \mathrm{pg}$ of K562 RNA or ALL-1 RNA with $1 \mu \mathrm{g}$ of HL60 RNA.

\section{RESULTS}

The challenge in developing a multiplex PCR is optimizing the reaction so that all targets are amplified at a similar efficiency. Competition for common reagents ( $\mathrm{Taq}$ polymerase and nucleotides) should be equalized during amplification. We found that an adjustment in primer concentrations was the most effective way to obtain similar amplification efficiencies over a broad range of target concentrations. In our optimized reaction the primer pairs for $\beta 2, \mathrm{p} 210$, and $\mathrm{p} 190$ are at a molar ratio of 1:2:0.7, respectively. No other adjustments of PCR reactants were necessary. Figure 2

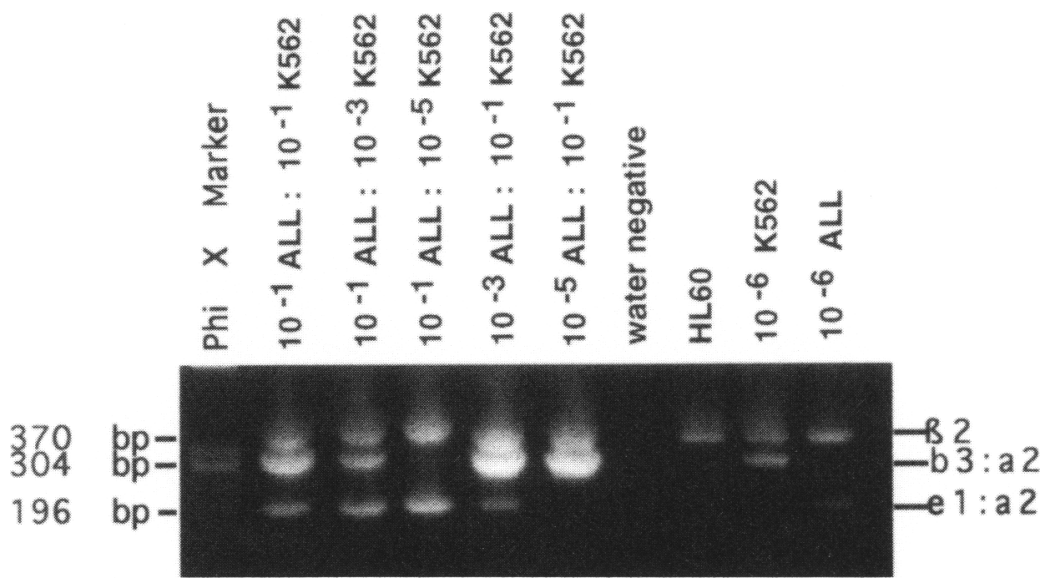

FIGURE 2 Optimization of multiplex PCR. Various primer concentrations were run on a dilution series in which varying concentrations of RNA from the K562 cell line (b3:a2 mRNA) and from the ALL-1 cell line (e1:a2 mRNA) were diluted into $1 \mu \mathrm{g}$ of HL60 RNA. The best equalized amplification of target RNA occurred when the molar ratio of $\beta 2, p 210$, and p190 primers were $1: 2: 0.7$, respectively. Amplification of both the p210 and p190 targets takes place when there is a two-log difference in concentration (lanes 3,5); however, at a four-log difference, the dominant target preferentially amplifies (lanes 4,6 ).

shows a PCR amplification of p210, p190, and $\beta 2$ gene targets using the optimized primer concentrations. Also demonstrated in Figure 2 is the fact that an equal amplification of $\mathrm{p} 210$ and $\mathrm{p} 190$ PCR products at a sensitivity of $10^{-3}$ is obtained when the concentration of one target RNA diminishes relative to the constant concentration of the other. However, when one target is in greater excess to another (e.g., when the concentration of the ALL-1 RNA is at a $10^{-1}$ dilution compared with a $10^{-5}$ dilution of K562 RNA), the multiplex PCR favors the amplification of the target that is more abundant (Fig. 2, lanes 4,6).

Multiplex PCR was found to be sensitive enough to detect p210 and p190 targets in conditions of very low target copy number. Figure 3 shows a serial dilution of K562 and ALL-1 RNAs in a constant background of $1 \mu \mathrm{g}$ of HL60 RNA across a range of $10^{-1}$ to $10^{-6}$ dilutions. Under the optimized primer concentrations, the p210 (b3:a2) and p190 (e1:a2) bcr$a b l$ mRNAs can be detected at a sensitivity of $10^{-5}$. When a single fusion transcript is diluted in a background of $1 \mu \mathrm{g}$ of HL60, a sensitivity of $10^{-6}$ can be obtained (Fig. 3, lanes labeled $10^{-6} \mathrm{~K} 562$ and $10^{-6}$ ALL-1).

The accuracy of multiplex PCR was tested by comparing results of patient samples run by multiplex PCR to the same patient samples run by the single primer approach. Figure 4 shows nine patient samples that were in accordance by both methods. In Figure $4 a$ the results of multiplex PCR are shown, Figure $4 \mathrm{~b}$ demonstrates the results of p190 amplification using p190 primers alone, and Figure 4c shows the results of p210 amplification using only p210-specific primers. Three of the samples were from three Ph + ALL patients $(8124,6056$, 8014), two were from a negative control $\mathrm{Ph}$ - ALL patient (8278), and the other four were from two CML patients (7291, 6318 ). CML patient 6318 has a p190 bcr$a b l$ rearrangement by multiplex PCR and p190 single-primer PCR and is negative for p210 bcr-abl transcripts by multiplex PCR and p210 single-primer PCR.

\section{DISCUSSION}

Analysis of Ph + ALL patients by PCR can be labor intensive because a large number of reaction tubes are needed to look for $b c r-a b l$ fusion transcripts. PCR screening of $\mathrm{Ph}+$ ALL patients requires three sets of reaction tubes per patient specimen ( $\beta 2$, p190, and p210 amplifications) because $\leqslant 50 \%$ of adult $\mathrm{Ph}+\mathrm{ALL}$ patients harbor the p210 bcr-abl chimeric transcript. The knowledge of the type of $b c r-a b l$ transcript may have importance in prognosis and in following the patient for minimal residual disease (MRD) throughout the course of therapy. Recently we have described a trend for ALL patients with the p190 break- 


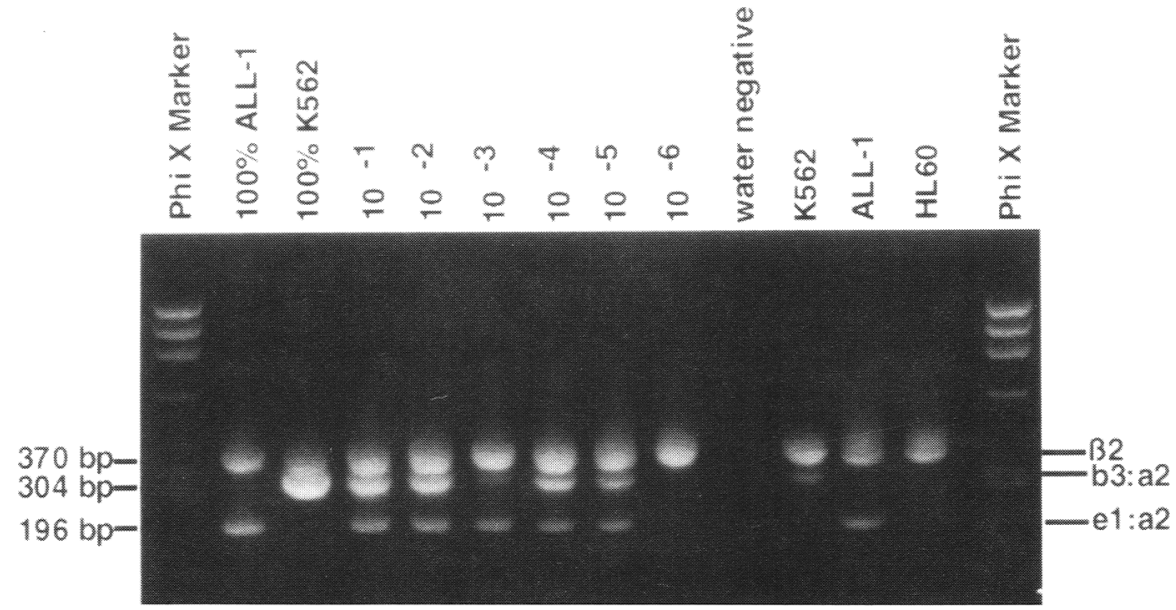

FICURE 3 Sensitivity of the multiplex PCR. Serially diluted RNA from the K562 and ALL-1 cell lines were mixed with $1 \mu \mathrm{g}$ of HL60 RNA. Four positive control RNAs were used: 100\% ALL-1, $100 \% \mathrm{~K} 562$, a $10^{-6} \mathrm{ALL}-1$ control, and a $10^{-6} \mathrm{~K} 562$ control. A nucleic acid negative reaction (water negative) and an HL60 RNA reaction were used as negative controls. Signals from the amplification of p210 and p190 bcr-abl rearrangement sequences can be detected down to the $10^{-5}$ dilution level. point to have an inferior, disease-free survival compared with patients with the p210 transcript. ${ }^{(10)}$ The use of the multiplex PCR will allow us to test this hy- pothesis on large numbers of patients in a cost-effective fashion.

An additional benefit of the described multiplex approach is derived by com-

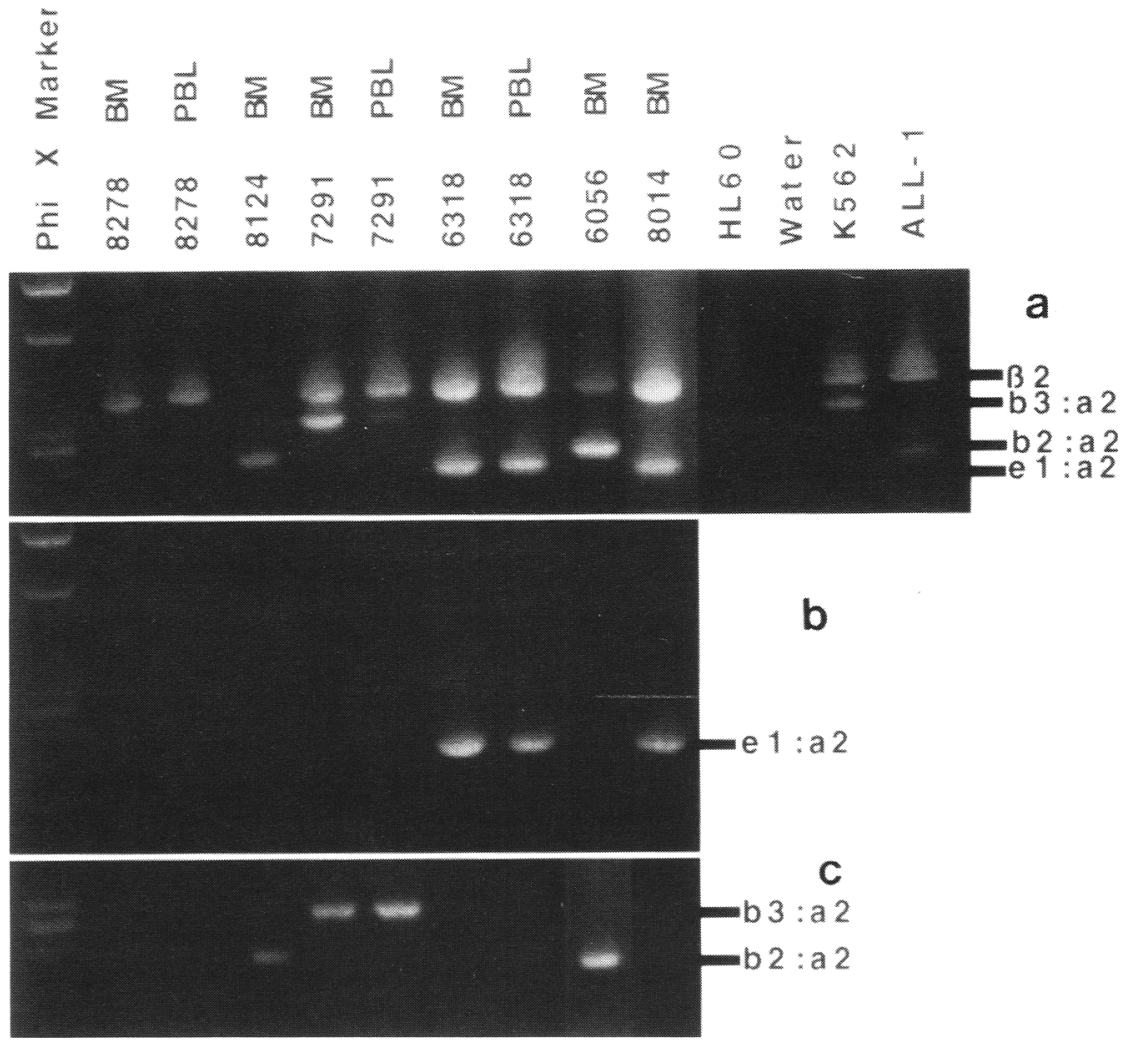

FIGURE 4 Patient series. A comparison of multiplex PCR to single-primer PCR on nine patient samples. UPN numbers and the specimen type [bone marrow (BM) or peripheral blood (PBL)] are designated. (a) Multiplex PCR; (b) single-primer p190 PCR; (c) single-primer p210 PCR. The controls shown at the right of $a$ were from the multiplex PCR. bining the initial reverse transcription reaction with the first PCR ingredients, which further simplifies and shortens the procedure. Thus, taken as a whole, the multiplex PCR approach reduces time and effort and eliminates several opportunities for operator error and PCR contamination. In addition, the multiplex PCR saves valuable RNA needed for duplicate or triplicate PCRs that confirm the accuracy of PCR analysis. Instead of dividing an equal amount of RNA into two or three reaction tubes, a single aliquot of RNA is needed for the one multiplex PCR reaction tube.

The multiplex PCR assay introduced in this paper has a high degree of sensitivity and specificity similar to nested, single-primer PCR. Thus, it has potential for not only diagnostic evaluation of $\mathrm{Ph}+$ leukemias but may also be used for sensitive monitoring of MRD throughout the course of treatment.

\section{ACKNOWLEDGMENTS}

We thank Lemoyne Mueller, the laboratory of Dr. Beverly Torok-Storb, and Tim Knight for their assistance. All figures were created using Deneba Canvas 3.0 and Adobe Photoshop. This work was supported by grant CA18029 from the National Cancer Institute.

\section{REFERENCES}

1. Kawasaki, E.S., S.S. Clark, M.Y. Coyne, S.D. Smith, R. Champlin, O.N. Witte, and F.P. McCormick. 1988. Diagnosis of chronic myeloid and acute lymphocytic leukemias by detection of leukemia-specific mRNA sequences amplified in vitro. Proc. Natl. Acad. Sci. 85: 5698-5702.

2. de Klein, A., A. Hagemeijer, C.R. Bartram, R. Houwen, L. Hoefsloot, F. Carbonell, L. Chan, M. Barnett, M. Greaves, E. Kleihauer, N. Haeisterkamp, J. Groffen, and G. Grosveld. 1986. BCR rearrangement and translocations of the C-ABL oncogene in Philadelphia positive acute lymphoblastic leukemia. Blood 68: 13691375.

3. Gehly, G.B., E.M. Bryant, A.M. Lee, P.G. Kidd, and E.D.T. Thomas. 1991. Chimeric bcr-abl messenger RNA as a marker for minimal residual disease in patients transplanted for Philadelphia chromosome-positive acute lymphoblastic leukemia. Blood 78: 458-465.

4. Guo, J.Q., C.F. Hirsch-Ginsberg, Y.M. Xian, S.A. Stass, R.E. Champlin, S.A. Giralt, K.B. McCredie, M.L. Campbell, and 
R.B. Arlinghaus. 1993. Acute lymphoid leukemia molecular phenotype in a patient with benign-phase chronic myelogenous leukemia. Hematol. Pathol. 7: 91.

5. Kirk, J.A., J.P. Radich, S.D. Edmands, A.M. Lee, D.R. VanDevanter, J.A. Reems, and E.M. Bryant. (in prep.).

6. Thomas, E.D., R.A. Clift, A. Fefer, F.R. Appelbaum, P. Beatty, W.I. Bensinger, C.D. Buckner, M.A. Cheever, H.J. Deeg, K. Doney, N. Flournoy, P. Greenberg, J.A. Hansen, P. Martin, R. McGuffin, R. Ramberg, J.E. Sanders, J. Singer, P. Stewart, R. Storb, K. Sullivan, P.L. Weiden, and R. Witherspoon. 1986. Marrow transplantation for the treatment of chronic myelogenous leukemia. Ann. Intern. Med. 104: 155.

7. Maniatis, T., E.F. Fritsch, and J. Sambrook. 1983. Molecular cloning: A laboratory manual. Cold Spring Harbor Laboratory, Cold Spring Harbor, New York.

8. Chomczynski, P. and N. Sacchi. 1987. Single-step method of RNA isolation by acid guanidinium thiocyanate-phenol-chloroform extraction. Anal. Biochem. 162: 156159.

9. Maurer, J., J.W. Janssen, E. Thiel, J. van Denderen, W.D. Ludwig, U. Aydemir, B. Heinze, C. Fonatsch, J. Harbott, A. Reiter, H. Riehm, D. Hoelzer, and C.R. Bartram. 1991. Detection of chimeric BCR-ABL genes in acute lymphoblastic leukaemia by the polymerase chain reaction. Lancet 337: 1055-1058.

10. Radich, J.P., K.J. Kopecky, D.H. Boldt, D. Head, M.L. Slovak, R. Babu, J. Kirk, A. Lee, P. Kessler, F. Appelbaum, and G. Gehly. 1994. Detection of BCR-ABL fusion genes in adult lymphoblastic leukemia by the Polymerase Chain Reaction. Leukemia 8: 1688-1695

Received October 19, 1994; revised version accepted February 14, 1995. 


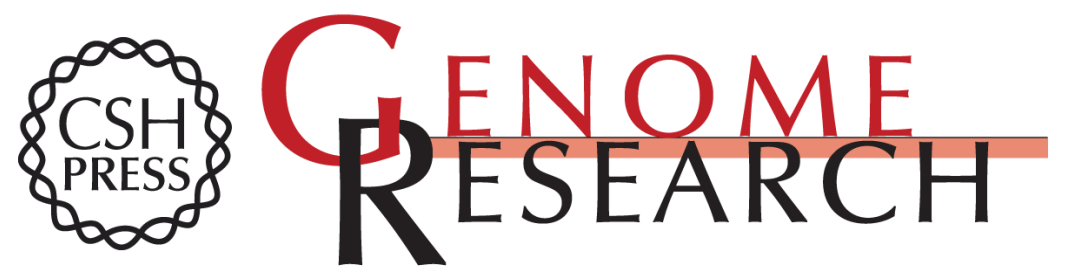

\section{Multiplex PCR of bcr-abl fusion transcripts in Philadelphia positive acute lymphoblastic leukemia.}

A Lee, J Kirk, S Edmands, et al.

Genome Res. 1995 4: 283-287

References This article cites 8 articles, 3 of which can be accessed free at: http://genome.cshlp.org/content/4/5/283.full.html\#ref-list-1

License

Email Alerting

Receive free email alerts when new articles cite this article - sign up in the box at the Service top right corner of the article or click here.

\section{Affordable, Accurate Sequencing.}

To subscribe to Genome Research go to: https://genome.cshlp.org/subscriptions 